\title{
Effect: An Empirical Study of Social Contribution and its Management Activities
}

\author{
Bin Jang ${ }^{1}$ and Ha-Kyun $\mathrm{Kim}^{2}$ \\ ${ }^{1}$ Doctoral Student of Graduate School of Information Systems, Pukyong National \\ Univ. 45, Yongso-ro, Nam-Gu, Busan, Korea \\ ${ }^{2}$ Professor (Corresponding Author) of Division of Business, Pukyong National Univ. \\ 45, Yongso-ro, Nam-Gu. Busan, Korea \\ 1bin8423@gmail.com, ${ }^{2}$ kimhk@pknu.ac.kr
}

\begin{abstract}
This study are as follows: First, it has been shown that social responsibility has a significant influence on the social environment (economy, politics, society and finance). Second, the social environment in the economy, politics, and finance had a significant influence on corporate value, but the social environment in the social aspect did not have a significant influence on corporate value. This has been empirically demonstrated by this paper that social responsibility is not an investment in the vague value of the social environment on the society. Thus, an entity can enhance its value in an economy, politics and finance of social environment by routinely performing its social responsibilities on the basis of profits generated by its management activities.
\end{abstract}

Keywords: Social responsibility, Economy, Politics, Society, Finance, Corporate value

\section{Introduction}

The recent social environment has a strong request for social responsibility in various fields of society. The number of clients aggressively expressing social responsibility for individualism, boycotts and investments is increasing [1]. Companies agree on the need for social responsibility but are passive in social contribution activities. This is because corporations consider social contribution not as investment but as expense. Corporate social responsibility is not mandatory. Therefore, companies are not financially certain about the value of social responsibility, such as investment.

Corporate stakeholders cannot make strategic decisions about social responsibility that are effective for the company. The company's stakeholders can analyze the relationship with the company and then prioritize social responsibility activities to strategically associate with the company [2].

The main purpose of this research is to analyze the special effects of social responsibility on social environment and corporate value. This study is established complete previous studies. Research results were derived through empirical analysis. First, corporate social responsibility has an influence the social environment (economy, politics, society, finance) for analyzing this research. Second, social environment effects on corporate value.

Article history:

Received (July 21, 2019), Review Result (September 9, 2019), Accepted (October 23, 2019) 


\section{Theoretical background}

\subsection{Corporate social responsibility}

The perception of Corporate Social Responsibility (CSR) was primary suggested by researchers in the 1930s. It is beginning to take shape in the 1960s. This is important for corporate social responsibility to behave in a manner that is consistent with the goals and values of society [3]

\subsection{Social environment (economy and politics)}

In order to effectively carry out the social functions of the economic side, firms decide on the direction to maximize profits in market competition [4]. Companies did not validate social responsibility for the economy and politics in order to maximize corporate profits [5]

\subsection{Social environment (society and finance)}

Companies benefit from social responsibility by improving employee morale and productivity. This is the basis for the debate that good companies have good ethics from a social point of view [6]. Investigating the link between social responsibility and corporate business performance proved that large companies with good social contributions performed better. It is examined the effects of corporate value and corporate financial performance on listed companies[3] Corporate social responsibility along with stakeholders of major companies in terms of consumers, employees and communities, ultimately had a positive impact on corporate profits.

\subsection{Corporate value}

The creation of corporate value is achieved through a routine management system [7].

\section{Research design}

\subsection{Research model}

The research focuses on analyzing the relationship between social responsibility and social environment (economy, politics, society and finances) and corporate value. Founded on the previous study, the research model is offered in [Figure 1].

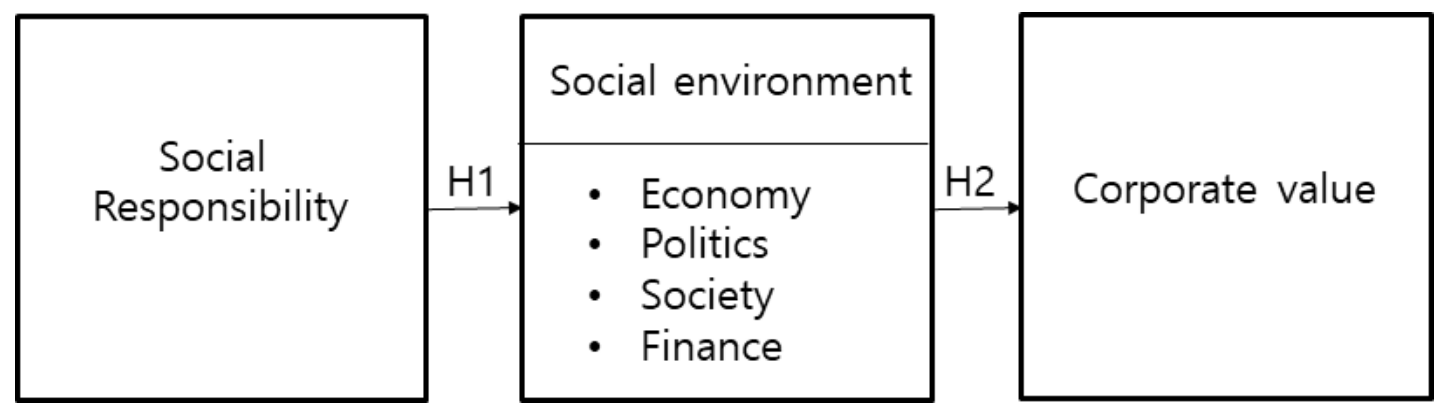

Figure 1. Research Model 


\subsection{Research hypothesis}

\subsubsection{Hypothesis about social responsibility and social environment}

The social environment is divided into four categories: economic, political, social, and financial factors.

Hypothesis 1: Social responsibility has a significant influence social environment.

H1-1: Social responsibility has a significant influence the economy.

H1-2: Social responsibility has a significant influence politics.

H1-3: Social responsibility has a significant influence society.

H1-4: Social responsibility has a significant influence finances.

\subsubsection{Hypothesis about social environment and corporate value}

The social environment can be a decisive factor in business value. It is stated in the previous study that social responsibility influences corporate value [3].

Hypothesis 2: Social environment has a significant influence corporate value.

H2-1: Economy has a significant influence corporate value.

H2-2: Politics has a significant influence corporate value.

$\mathrm{H} 2-3$ : Society has a significant influence corporate value.

H2-3: Finance has a significant influence corporate value.

\subsection{Empirical analysis and results}

\subsubsection{Analysis method of data}

For the analysis of the survey, it is used Smart PLS 2.0 for the structural equation. Concentration validity checks factor loading, compositional reliability (C.R.) and variance extraction index (AVE) of each factor. In general, factor loading value is 0.6 or more, configuration reliability value is 0.7 or more and variance extraction index value is 0.5 or more. to be.

The discriminant validity has no problem in discriminant validity since the square root value of the variance extraction index is compared with the correlation coefficient.

Table 1. Reliability and internal consistency

\begin{tabular}{|c|c|c|c|c|}
\hline Variables & Factor Loading & AVE & C. R. & Cronbach's $\alpha$ \\
\hline \multirow{4}{*}{$\begin{array}{c}\text { Social } \\
\text { responsibility }\end{array}$} & 0.791 & \multirow{4}{*}{0.756} & \multirow{4}{*}{0.929} & \multirow{4}{*}{0.898} \\
\hline & 0.882 & & & \\
\hline & 0.912 & & & \\
\hline & 0.913 & & & \\
\hline \multirow{3}{*}{ Economy } & 0.863 & \multirow{3}{*}{0.744} & \multirow{3}{*}{0.908} & \multirow{3}{*}{0.848} \\
\hline & 0.892 & & & \\
\hline & 0.871 & & & \\
\hline \multirow{3}{*}{ Politics } & 0.960 & \multirow{3}{*}{0.844} & \multirow{3}{*}{0.977} & \multirow{3}{*}{0.966} \\
\hline & 0.975 & & & \\
\hline & 0.966 & & & \\
\hline
\end{tabular}




\begin{tabular}{|c|c|c|c|c|}
\hline \multirow{3}{*}{ Society } & 0.977 & \multirow{3}{*}{0.835} & \multirow{3}{*}{0.974} & \multirow{3}{*}{0.960} \\
\hline & 0.897 & & & \\
\hline & 0.956 & & & \\
\hline \multirow{3}{*}{ Finances } & 0.972 & \multirow{3}{*}{0.871} & \multirow{3}{*}{0.960} & \multirow{3}{*}{0.938} \\
\hline & 0.897 & & & \\
\hline & 0.956 & & & \\
\hline \multirow{4}{*}{ Corporate value } & 0.819 & \multirow{4}{*}{0.781} & \multirow{4}{*}{0.930} & \multirow{4}{*}{0.899} \\
\hline & 0.845 & & & \\
\hline & 0.941 & & & \\
\hline & 0.892 & & & \\
\hline
\end{tabular}

Table 2. Correlation and discriminant validity

\begin{tabular}{|c|c|c|c|c|c|c|c|}
\hline Variables & AVE & 1 & 2 & 3 & 4 & 5 & 6 \\
\hline Social responsibility & 0.756 & $\mathbf{0 . 8 6 9}$ & & & & & \\
\hline Economy & 0.744 & 0.356 & $\mathbf{0 . 8 6 2}$ & & & & \\
\hline Politics & 0.844 & 0.613 & 0.490 & $\mathbf{0 . 9 1 8}$ & & & \\
\hline Society & 0.835 & 0.512 & 0.567 & 0.387 & $\mathbf{0 . 9 1 3}$ & & \\
\hline Finances & 0.871 & 0.387 & 0.389 & 0.423 & 0.289 & $\mathbf{0 . 9 3 3}$ & \\
\hline Corporate value & 0.781 & 0.465 & 0.641 & 0.671 & 0.341 & 0.441 & $\mathbf{0 . 8 3 1}$ \\
\hline
\end{tabular}

\subsubsection{Verification of research model}

For the structural model analysis, the hypothesis was verified using Smart PLS 2.0. the coefficient of determination $\left(\mathrm{R}^{2}\right)$ were derived. If $\mathrm{R}^{2}$ is greater than 0.26 , then the model fits. If $\mathrm{R}^{2}$ is less than $0.26-0.13$ or 0.13 , then the suitability is medium or low [8]. As shown in [Figure $2]$, the coefficients of determination of politics (0.366) and society $(0.250)$ are high. The coefficients of determination of the economy (0.136), finance $(0.158)$ and enterprise value (0.191) are intermediate.

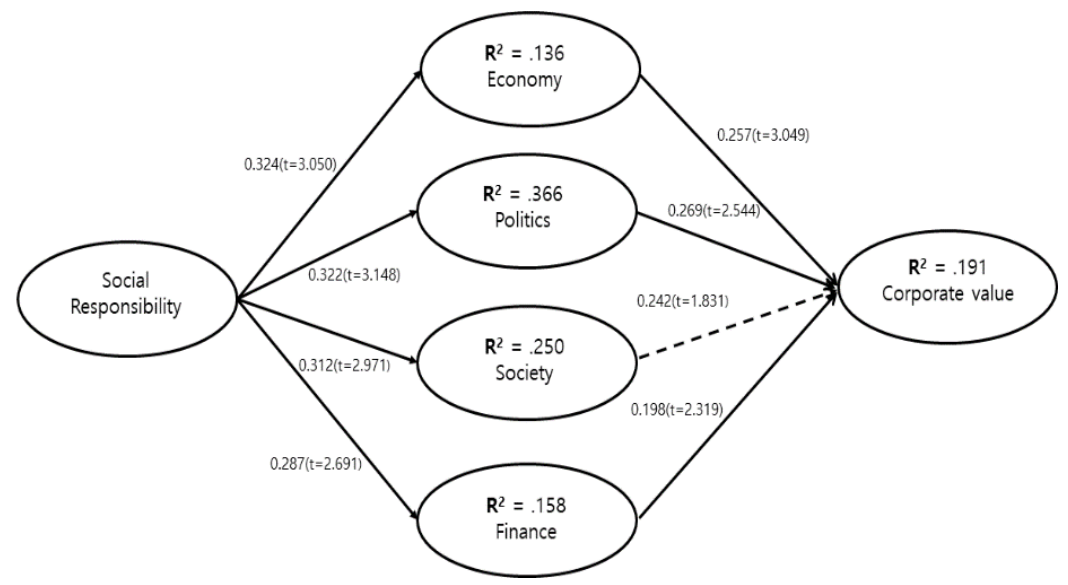

Figure 2. The results of research model 
Hypothesis H1-1, social responsibility and economy $(\beta=0.324, t=3.050)$ have significant effects.

Hypothesis $1-2$, social responsibility and politics $(\beta=0.322, \mathrm{t}=3.148)$ were found to have a significant effect.

Hypothesis $1-3$, social responsibility and society $(\beta=0.312, t=2.971)$ were found to have a significant effect.

Hypothesis $1-4$, social responsibility and finance $(\beta=0.287, \mathrm{t}=2.691)$ were found to have a significant effect.

Hypothesis $2-1$, economic and corporate value $(\beta=0.257, t=3.049)$ were found to have a significant effect.

Hypothesis $2-2$, politics and enterprise value $(\beta=0.366, t=2.544)$ had a significant effect.

Hypothesis $2-3$, social and business values $(\beta=0.242, \mathrm{t}=1.831)$ had no significant effect.

Hypothesis $2-4$, finance and firm value $(\beta=0.198, \mathrm{t}=2.319)$ were found to have a significant effect.

\section{Conclusion}

This study examined the connection among social responsibility, social environment and corporate value through empirical research. Empirically, corporate social responsibility has a significant role in growing corporate value.

The main results can be summarized as follows. First, corporate social responsibility had a significant influence on the social environment (economy, politics, society and finance). Second, in the social environment, the economy, politics, and finances had an effect on corporate value, but society did not. Social responsibility has an influence on the economy, politics, society and finance. This paper empirically demonstrates that social responsibility is not mandatory but is not an investment of the vague value of the social environment. Firms must continue to work for their profit. To this end, corporate social responsibility is an appropriate corporate activity that can rise the value of a corporation. In order to increase social responsibility and corporate value, firms have practice social responsibility by developing a social responsibility model. It can be directly helped to major corporate actions and social responsibility.

Based on this research, the research model of corporate social responsibility, social environment, and corporate value was presented. In future research, it is necessary to expand the parameters for the social environment in various ways.

\section{References}

[1] R. Hamann, “Mining Companies' Role in Sustainable Development: the 'Why' and 'How' of Corporate Social Responsibility from a Business Perspective,” Development Southern Africa, vol.20, no.2, pp.234-145, (2003) DOI: $10.1080 / 03768350302957$

[2] A. Carroll and K. M. Shabana, "The business case for corporate social responsibility: A review of concepts research and practice," International Journal of Management Reviews, vol.12, no.3, pp.85-105, (2010) DOI: 10.1111/j.1468-2370.2009.00275.x

[3] J. Choi, H. Shin and A. Nasridinove, "A comparative study on data mining classification techniques for military application,” Human-centric Computing and Information Sciences, vol.7, no.2, pp.1-14, (2016) 
[4] W. C. Fredrick, "Corporate social responsibility in the Reagan era and beyond," California Management Review, vol.25, no.3, pp.145-157, (1984) DOI: 10.2307/41165022

[5] M. B. Clarkson E. "A stakeholder framework for analyzing and evaluating corporate social performance," Academy of Management Review, vol.20, no.1, pp.92-117, (1995) DOI: 10.5465/amr.1995.9503271994

[6] J. D. Westphal, "Collaboration in the Boardroom: Behavioral and performance Consequences of CEO-board Social Ties,” Academy of Management Journal, vol.42, no.1, pp.7-24, (1999) DOI: 10.5465/256871

[7] S. Vera, S. Selo and W. Widyawan, "Internet of Things (IoT) framework for granting trust among objects," Journal of Information Processing Systems, vol.13, no.6, pp.1613-1627, (2017)

[8] J. Cohen, Statistical Power Analysis for the Behavioral Science (2nd ed.), Hillside, New Jersey: Lawrence Erlbaum, (1998) 